\title{
DEVELOPMENT AND VALIDATION OF STABILITY INDICATING RP-HPLC METHOD FOR DETERMINATION OF CERITINIB
}

\begin{abstract}
Vaibhav Suresh Adhao ${ }^{1}$, J. Sharma², M. Thakare ${ }^{2}$
1DR. Rajendra Gode College Of Pharmacy, Malkapur. Maharashtra, India - 443101 ${ }^{2}$ Dr. B.R. Ambedkar University, Agra, Uttar Pradesh, India - 282004

Submitted: $12-09-2017$

Revised: 28-11-2017

Accepted: 03-12-2017

*Corresponding author Vaibhav Suresh Adha

Email:

adhao.vaibhav@gmail.com

ABSTRACT

The purpose of the present work was to develop new, simple, specific, accurate and precise stability indicating RP-HPLC method for determination of ceritinib. In the present study, stress testing of ceritinib was carried out according to ICH guidelines Q1A (R2). ceritinib was subjected to stress conditions of hydrolysis, oxidation, photolysis and neutral decomposition. Extensive degradation was found to occur in acidic condition. Mild degradation was observed in basic and at thermal conditions. Successful separation of drug from degradation products formed under stress conditions was achieved on a Hypersil BDS C18 column $(250 \times 4.6 \mathrm{~mm}, 5.0 \mu$ particle size $)$ using acetonitrile: acetate buffer $(\mathrm{pH} 3.7 \pm 0.05)(50: 50 \mathrm{v} / \mathrm{v})$, at a flow rate of $1.0 \mathrm{~mL} / \mathrm{min}$ and column was maintained at $40^{\circ} \mathrm{C}$. Quantification and linearity were achieved at $272 \mathrm{~nm}$ over the concentration range of $5-100 \mu \mathrm{g} / \mathrm{mL}$ for ceritinib. The Correlation Coefficient was found to be 0.9960 . The method was validated for specificity, linearity, accuracy, precision, LOD, LOQ and robustness. The developed method will be useful for routine analysis for samples of stability studies in the formulation and development.
\end{abstract}

Keywords: Stability-indicating, HPLC, ceritinib, validation, stress testing.

\section{INTRODUCTION}

Ceritinib,

5-Chloro-N4-[2-[(1-

methylethyl)sulfonyl]phenyl]-N2-[5-methyl-2-

(1-methyl-ethoxy)-4-(4-piperidinyl)phenyl] 2,4pyrimidine diamine, is an anaplastic lymphoma kinase (ALK) inhibitor which induces complete tumor regression in a xenograft model of EML4-ALK-positive lung cancer. The alternative names of ceritinib are LDK 378, NVP-LDK 378, ZykadiaTM. Ceritinib is a highly selective inhibitor of an important cancer target, ALK (Heudi, et. al., 2014). Ceritinib, a recently approved drug by Food and Drug Administration, is used for the treatment of late-stage (metastatic) non-small cell lung cancer (Waters, 2014). The recommended dosage of ceritinib is $750 \mathrm{mg}$ administered orally once daily on an empty stomach (Shaw, $e t$ al., 2014). The chemical structure of ceritinib (Figure 1).

An ultrafast, sensitive, selective, and robust LDTD-APCI-MS/MS method was developed for the quantification of ceritinib in human plasma (Lanshoeft, 2015). A stability<smiles>Cc1cc(Nc2ncc(Cl)c(Nc3ccccc3S(=O)(=O)C(C)C)n2)c(OC(C)C)cc1C1CCNCC1</smiles>

Figure 1. Structure of Ceritinib

indicating reversed-phase high-performance liquid chromatographic (RP-HPLC) method for estimation of ceritinib was reported (Kumar., 2014). Since, there are only two HPLC method reported in the literature for the estimation of ceritinib in pharmaceutical dosage forms 
(Chintala, et al., 2015), (Reddy, et al., 2016 ), therefore, there is a need to develop quantitative methods under different conditions to achieve improvement in sensitivity, selectivity, as per ICH guidelines (2005). The developed method will be novel for Stability studies and use in the routine analysis for samples in stability study which was very important part of formulation and development.

\section{MATERIAL AND METHODS Reagents and materials}

Ceritinib (purity $>99 \%$ ) procured from Spectrum lab, Hyderabad, India was used for the study. All the chemicals used of HPLC Grade (MERCK. Chem. Ltd., Mumbai) and HPLC grade water was used for mobile phase preparation. Nylon membrane filter $0.45 \mu$ syringe filter. Hydrogen peroxide, sodium hydroxide and hydrochloric acid are used of AR grade.

\section{Chromatographic conditions:}

The chromatographic separation was achieved on Perkin Elmer (USA) HPLC system (series 200) equipped with Perkin Elmer series 200 pump system having back pressure 5000 psi, manual injector of $20 \mu \mathrm{L}$ loop, UV-Visible detector and Hypersil BDS C18 column $(250 \mathrm{~mm} \times 4.6 \mathrm{~mm}$ i.d., $5 \mu \mathrm{m})$; Sartorious, analytical balance; An ultra-sonicator; A Shimadzu model 1800 double beam UV/Vis. spectrophotometer with a pair of $10 \mathrm{~mm}$ matched quartz cells. The mobile phase comprised of acetonitrile: acetate buffer $(\mathrm{pH} \quad 3.7 \pm 0.05)$ $(60: 40 \% \mathrm{v} / \mathrm{v})$, at a flow rate of $1.0 \mathrm{~mL} / \mathrm{min}$, and column was maintained at $40^{\circ} \mathrm{C}$. The mobile phase was filtered through nylon $0.45 \mu \mathrm{m}$ membrane filter and was degassed before being used for analysis. The UV-Visible detector was set at $272 \mathrm{~nm}$. The injection volume was $20 \mu \mathrm{L}$ and total run time was $10 \mathrm{~min}$.

\section{Preparation of the mobile phase}

The mobile phase was prepared by mixing $60 \mathrm{~mL}$ acetonitrile and $40 \mathrm{~mL}$ acetate buffer ( $\mathrm{pH} \quad 3.7 \pm 0.05)$ previously filtered through $0.45 \mu \mathrm{m}$ nylon membrane filter. The mobile phase was degassed for $15 \mathrm{~min}$ by sonicating the solution before use.

\section{Preparation of Diluent}

Acetonitrile: Water $(60: 40 \% \mathrm{v} / \mathrm{v})$ was used as diluent.

\section{Preparation of standard solution}

Accurately weighed ceritinib $(25 \mathrm{mg}$ ) was transferred to a $25 \mathrm{~mL}$ volumetric flask, dissolved in and diluted to the mark with diluent to obtain a standard stock solution $(1 \mathrm{mg} / \mathrm{mL})$.

\section{Preparation of working standard solution $(10 \mu \mathrm{g} / \mathrm{mL})$ \\ Standard solution $(0.1 \mathrm{~mL})$ was} transferred in a $10 \mathrm{~mL}$ volumetric flask and diluted up to the mark with mobile phase.

\section{Analysis of tablet dosage form}

Twenty tablets (ZYKADIA) were weighed and average weight was calculated. The tablets were finely powdered, and a quantity of powder equivalent to $25 \mathrm{mg}$ ceritinib was weighed accurately and transferred to a $25 \mathrm{~mL}$ volumetric flask containing $15 \mathrm{~mL}$ diluent, and sonicated for $15 \mathrm{~min}$. The solution was allowed to stand at room temperature for $5 \mathrm{~min}$ and the volume was made up to the mark with diluent to obtain the sample stock solution $(1 \mathrm{mg} / \mathrm{mL})$. The solution was filtered through $0.45 \mu$ membrane filter. Aliquot $(1.0 \mathrm{~mL})$ was taken and transferred to $10 \mathrm{~mL}$ volumetric flask and volume was made up to the mark with diluent to give a solution containing $100 \mu \mathrm{g} / \mathrm{mL}$ ceritinib. The solution $(2.0 \mathrm{~mL})$ was transferred to $10 \mathrm{~mL}$ volumetric flask and diluted up to the mark with mobile phase to give a solution containing $20 \mu \mathrm{g} / \mathrm{mL}$ ceritinib. An aliquot $(20 \mu \mathrm{L})$ was injected and the chromatogram was recorded. The peak area was noted and the amount of ceritinib was calculated from the regression equation.

\section{Forced degradation study}

Ceritinib was subjected to various forced degradation conditions to affect partial degradation of the drug preferably in $20-80 \%$ range. The study provided information about the conditions in which the drug was unstable. This Information was useful for development of formulation. 
Effect of acid, alkaline and neutral hydrolysis

Accurately weighed ceritinib $25 \mathrm{mg}$ was transferred to three different $100 \mathrm{~mL}$ volumetric flasks and dissolved in diluent $(20 \mathrm{~mL})$. Hydrochloric acid $(0.1 \mathrm{~N}, 10 \mathrm{~mL})$, sodium hydroxide $(0.1 \mathrm{~N}, 10 \mathrm{~mL})$ and water $(10 \mathrm{~mL})$ were added to separate flasks containing drug samples and mixed properly for acidic, alkaline and neutral degradation respectively and stored at room temperature for $72 \mathrm{~h}$.

The samples were neutralized with base or acid as appropriate and diluted up to the marks with diluent to obtain stock solutions $(250 \mu \mathrm{g} / \mathrm{mL})$. Dilutions were made with mobile phase to obtain the degraded ceritinib solutions $(25 \mu \mathrm{g} / \mathrm{mL})$.

\section{Effect of oxidation}

Accurately weighed ceritinib $25 \mathrm{mg}$ was transferred to a $100 \mathrm{~mL}$ volumetric flask and dissolved in diluent $20 \mathrm{~mL}$. Hydrogen peroxide solution $(3 \%) 10 \mathrm{~mL}$ was added, mixed, and stored at room temperature for $72 \mathrm{~h}$. The sample was diluted up to the mark with acetonitrile to obtain stock solution $(250 \mu \mathrm{g} / \mathrm{mL})$. Dilution was made with mobile phase to obtain the degraded Ceritinib solution $(25 \mu \mathrm{g} / \mathrm{mL})$.

\section{Effect of heat}

Ceritinib $25 \mathrm{mg}$ was distributed over a glass plate and kept in an oven at $60^{\circ} \mathrm{C}$ for $72 \mathrm{~h}$, then ceritinib was transferred in a $100 \mathrm{~mL}$ volumetric flask, and dilutions were made with mobile phase to obtain the degraded ceritinib solution $(25 \mu \mathrm{g} / \mathrm{mL})$.

\section{Effect of light}

Ceritinib solution (prepared by dissolving $25 \mathrm{mg}$ ceritinib in $20 \mathrm{~mL}$ acetonitrile in $100 \mathrm{~mL}$ volumetric flask) was exposed to sun light for $48 \mathrm{~h}$, while ceritinib powder $25 \mathrm{mg}$ was exposed to UV light for 48h. After exposure, dilutions were made to obtain the degraded ceritinib solutions $(25 \mu \mathrm{g} / \mathrm{mL})$. Aliquots $(20 \mu \mathrm{L})$ of the stressed samples were injected into the HPLC system as described under chromatographic conditions and the chromategrams were recorded.

\section{Method validation}

As per the ICH guideline Q2 (R1) (2005), the method validation parameters namely specificity, linearity, accuracy, precision, limit of detection, limit of quantitation and robustness were studied.

\section{Solution stability}

Sample solutions were kept at $25 \pm 2^{\circ} \mathrm{C}$ (24h) and $2-8^{\circ} \mathrm{C} \quad(3$ days), respectively. Assay percentage of initial time period was compared with these two time periods. The change in the assay percentage was calculated. The difference between assay results should not be more than $2 \%$ for formulation, and $0.5 \%$ for active pharmaceutical ingredient (API).

\section{Specificity}

Chromatograms of ceritinib solutions and degraded samples were studied in order to provide an indication of the stability indicating properties and specificity of the method. The stress conditions employed were acidic, alkaline, neutral, oxidative, thermal and photolytic degradation. The degraded samples were analyzed against freshly prepared sample solutions.

\section{Linearity (Calibration Curve)}

Standard solutions $(0.05,0.1,0.15,0.2$, 0.25 and $0.3 \mathrm{~mL}$ equivalent to $5.0,10.0,15.0$, $20.0,25.0$ and $30.0 \mu \mathrm{g} / \mathrm{mL}$ of ceritinib) were transferred in a series of $10 \mathrm{~mL}$ volumetric flasks and diluted to the mark with mobile phase. An aliquot $(20 \mu \mathrm{L})$ of each solution was injected under the operating chromatographic conditions as described earlier. Calibration curve was constructed by plotting peak areas versus concentrations, and the regression equation was calculated. Each response was average of three determinations.

\section{Accuracy (\% recovery)}

Accuracy of the method was determined by calculating percentage recovery of ceritinib by the standard addition method. Known amount of standard solutions of ceritinib $(0,5$, 10 and $15 \mu \mathrm{g} / \mathrm{mL}$ ) were added to a pre-analyzed sample solution of ceritinib $(10 \mu \mathrm{g} / \mathrm{mL})$. Each solution was injected in triplicate, and the percentage recovery was calculated by measuring the peak areas and fitting these values into the regression equation of the calibration curve. 
Precision

Repeatability was checked by repeatedly $(\mathrm{n}=6)$ injecting ceritinib solution $(10 \mu \mathrm{g} / \mathrm{mL})$ and recording the chromatogram. Intra-day and inter-day precisions of the developed method was determined by measuring the corresponding responses 3 times on the same day and on 3 different days over a period of 1 week for 3 different concentration of ceritinib $(10.0,20.0$ and $30.0 \mu \mathrm{g} / \mathrm{mL})$. The results were reported in terms of relative standard deviation.

Limit of detection and limit of quantification

Limit of detection (LOD) and the limit of quantification (LOQ) were calculated using the standard deviation of response $(\sigma)$ and slope (S) of the calibration curve.

$$
\begin{aligned}
& \mathrm{LOD}=3.3 \times \sigma / \mathrm{S} \\
& \mathrm{LOQ}=10 \times \sigma / \mathrm{S}
\end{aligned}
$$

\section{Robustness}

Robustness was studied by analyzing the samples of ceritinib by deliberate variation in the method parameters. The change in the response of ceritinib was noted. Robustness of the method was studied by changing the extraction time of ceritinib from tablet dosage form by $\pm 2 \mathrm{~min}$, composition of mobile phase by $\pm 2 \%$ of organic solvent, wavelength by \pm 2 $\mathrm{nm}$, flow rate by $\pm 0.2 \mathrm{~mL} / \mathrm{min}$ and column oven temperature by $2^{\circ} \mathrm{C}$. The changes in the response of ceritinib were noted and compared with the original one.

\section{System-suitability test}

System suitability tests were used to verify that the resolution and repeatability of the system were adequate for the analysis intended. The parameters used in this test were retention time, tailing factor and theoretical plates of chromatographic peak as RSD of peak area for replicate injections.

\section{RESULTS AND DISCUSSION Selection of column and mobile phase}

As per the published literature and knowledge of the molecule, reverse phase liquid chromatography (RP-HPLC) is suitable for analysis of ceritinib. In case of RP-HPLC various columns are available, but as the main aim of the method was to resolve the compound from degraded products, $\mathrm{C}_{18}$ column $(250 \times 4.6 \mathrm{~mm}$ i.d., $5 \mu \mathrm{m}$ particle size $)$ was preferred over the other columns. Resolution is the most important criteria for the method, it is imperative to achieve good resolution among the compound and degraded products. As per the value of $\mathrm{pKa}$ and solubility of compound various composition of mobile phase were tried.

The chromatographic conditions were optimized with a view to develop a stability indicating assay method, which can separate the drug from its degradation products with good resolution. Mobile phase consisting of acetonitrile: acetate buffer $(\mathrm{pH} \quad 3.7 \pm 0.05)$ $(50: 50 \% \mathrm{v} / \mathrm{v})$ at a flow rate of $1.0 \mathrm{~mL} / \mathrm{min}$, was found to be satisfactory to obtain well-resolved peaks with better reproducibility and repeatability for ceritinib (Figure 2).

\section{Method validation}

The change in assay results after storage at $25^{\circ} \mathrm{C}(24 \mathrm{~h})$ and $2-8^{\circ} \mathrm{C}$ ( 3 days) was evaluated. It was found that the difference in assay results was not more than $2 \%$ for formulation, and $0.5 \%$ for API, indicating stability of ceritinib solution.

The developed analytical method was found to be specific as there was no inference of any related impurities after the stress degradation study (Figure 3). It was shown that the ceritinib peaks were free from excipients and co-eluting impurities.

The linear correlation was obtained between peak area and concentration of ceritinib in the range of $5-30 \mu \mathrm{g} / \mathrm{mL}$, the linearity of the calibration curve was validated by the value of correlation coefficient of the regression ( $r$ ) and the $\mathrm{Y}$ intercept were found to be 0.9960 and $Y=38217 x+72833$ respectively. The regression analysis of the calibration curves (Table I).

The accuracy study was carried out by the standard addition method at level of $\pm 50 \%$ of standard concentration. The percent recoveries were found in the range of 98.86$101.12 \%$, which indicated accuracy of the method (Table II). The accuracy study had shown results within the limit of \% RSD less than $2 \%$. 


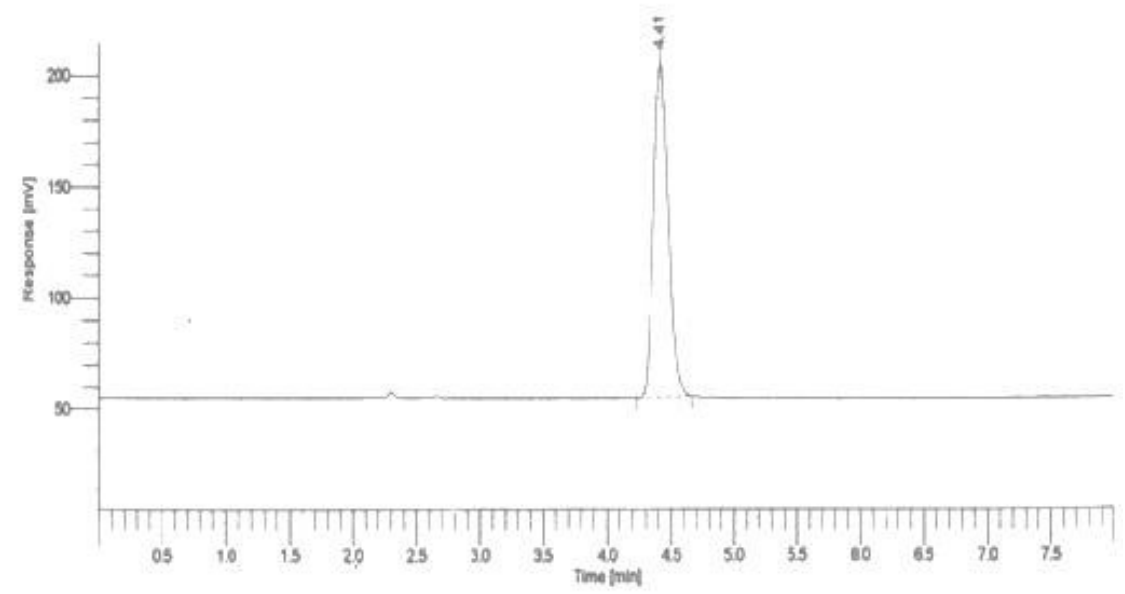

Figure 2. Chromatogram of ceritinib with retention time of $4.41 \mathrm{~min}$

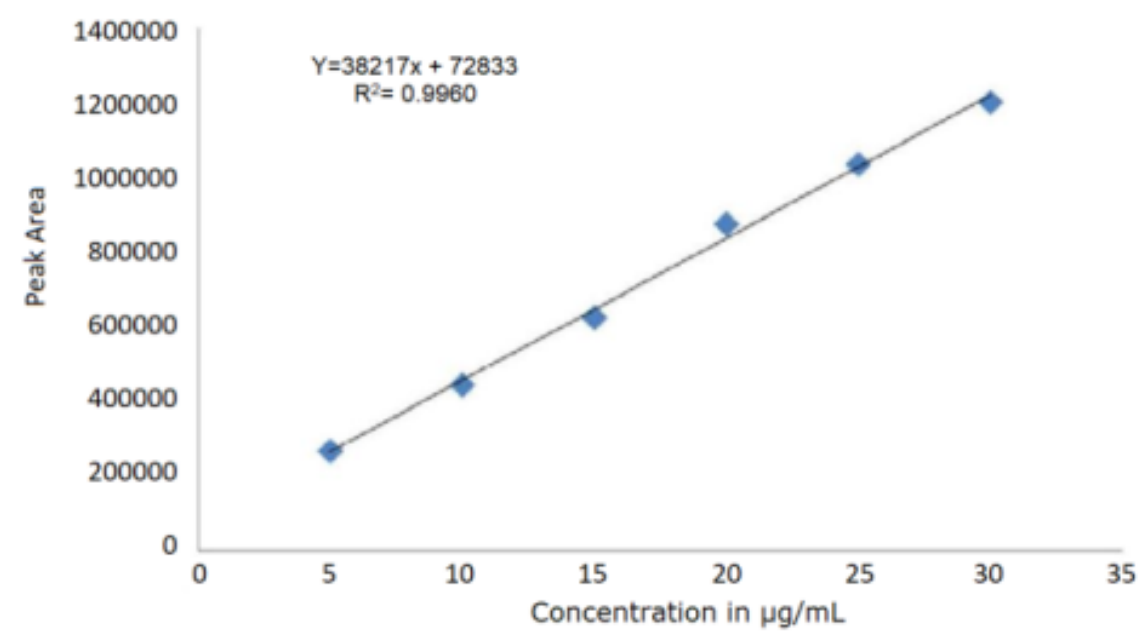

Figure 3. Calibration curve of ceritinib

The $\%$ RSD for repeatability (Table III) of ceritinib was found to be 1.25 . The value of $\%$ RSD for intra-day precision was found to be in the range of $0.93-1.15 \%$ and inter-day precision was found to be in the range of 1.07 $1.22 \%$, which indicated that the method was precise (Table IV). The Precision study showed results within the limit of $\%$ RSD less than $2 \%$. The Limit of detection (LOD) for ceritinib was found to be $0.062 \mu \mathrm{g} / \mathrm{mL}$, while the Limit of quantification (LOQ) was $0.187 \mu \mathrm{g} / \mathrm{mL}$. The method was found to be robust as the results were not significantly affected by slight variation in extraction time, composition of mobile phase, wavelength and flow rate of the mobile phase.

\section{System-suitability test}

The $\%$ RSD of retention time, tailing factor, and theoretical plates were found to be $1.26 \%, 1.08 \%$ and $0.46 \%$ respectively. The $\%$ RSD of system-suitability test parameters was found satisfactory as $\%$ RSD should not be more than $2 \%$ (Table V).

\section{Analysis of tablet dosage form}

The proposed RP-HPLC method was successfully applied for determination of ceritinib from tablet dosage form. The percentage of ceritinib was found to be 99.07\%; which was comparable with the corresponding label claim (Table VI). 
Table I. Optical and regression characteristics $(n=3)$

\begin{tabular}{cc}
\hline Parameter & Ceritinib \\
\hline Linearity range $(\mu \mathrm{g} / \mathrm{mL})$ & $5-30$ \\
Linearity equation & $\mathrm{y}=38217 \mathrm{x}+72833$ \\
LOD $(\mu \mathrm{g} / \mathrm{mL})$ & 0.062 \\
LOQ $(\mu \mathrm{g} / \mathrm{mL})$ & 0.187 \\
Correlation coefficient $(\mathrm{r})$ & 0.9960 \\
\hline
\end{tabular}

Table II. Results of recovery study ( $\mathrm{n}=3$ )

\begin{tabular}{cccrc}
\hline $\begin{array}{c}\text { Amount } \\
\text { Taken }(\boldsymbol{\mu g} / \mathrm{mL})\end{array}$ & $\begin{array}{c}\text { Amount } \\
\text { added }(\mu \mathrm{g} / \mathbf{m L})\end{array}$ & $\begin{array}{c}\text { Amount } \\
\text { Found }(\boldsymbol{\mu g} / \mathbf{m L})\end{array}$ & $\begin{array}{c}\text { Recovery } \\
\mathbf{\pm} \mathbf{S . D} \mathbf{0} \%\end{array}$ & $\begin{array}{c}\mathbf{\%} \\
\text { RSD }\end{array}$ \\
\hline 10 & 0 & 10.05 & $100.50 \pm 0.92$ & 0.92 \\
10 & 5 & 14.83 & $98.86 \pm 1.65$ & 1.65 \\
10 & 10 & 19.90 & $99.50 \pm 1.37$ & 1.37 \\
10 & 15 & 25.28 & $101.12 \pm 0.77$ & 0.77 \\
\hline
\end{tabular}

Table III. Results of repeatability $(n=6)$

\begin{tabular}{cccccccccc}
\hline Drug & $\mathbf{1}$ & $\mathbf{2}$ & $\mathbf{3}$ & $\mathbf{4}$ & $\mathbf{5}$ & $\mathbf{6}$ & Mean & SD & \% RSD \\
\hline $\begin{array}{l}\text { Ceritinib } \\
\text { Peak area }\end{array}$ & 443614.0 & 454953.1 & 443275.4 & 445228.7 & 448743.8 & 438564.2 & 445729.9 & 5590.19 & 1.25 \\
\hline
\end{tabular}

Table IV. Results of Intra-day and Inter-day precision $(n=3)$

\begin{tabular}{ccccc}
\hline Ceritinib & \multicolumn{2}{c}{ Intra-day precision } & \multicolumn{2}{c}{ Inter-day precision } \\
\cline { 2 - 5 }$(\boldsymbol{\mu g} / \mathbf{m L})$ & Mean peak area \pm SD & \% RSD & Mean peak area \pm SD & \% RSD \\
\hline 10 & $443614.0 \pm 4152.12$ & 0.91 & $448745.3 \pm 4836.18$ & 1.04 \\
20 & $875777.0 \pm 9638.35$ & 1.08 & $878418.6 \pm 9858.21$ & 1.07 \\
30 & $1200410.0 \pm 13864.16$ & 1.13 & $1201059.6 \pm 14728.26$ & 1.12 \\
\hline
\end{tabular}

\section{Degradation study}

Forced degradation study of ceritinib was carried out under various stress conditions as follows

\section{Effect of acid, alkaline and neutral hydrolysis}

Ceritinib was found to undergo $64.67 \%$ decomposition under acidic stress condition with a major degradation product at retention time of about $3.88 \mathrm{~min}$ and minor degradation product at retention time of about $2.30 \mathrm{~min}$ and minute decomposition about 3.7\% under basic stress condition with a degradation product at retention time of about $2.30 \mathrm{~min}$. Under neutral degradation condition, no degradation was observed. Hence, ceritinib was found to be highly degradable in basic condition, and very minute degradable in acidic condition but not degradable in neutral condition.

\section{Effect of oxidation}

In oxidation stress condition, almost $9.5 \%$ of ceritinib was degraded and degradation peak appeared in chromatogram at $2.30 \mathrm{~min}$ retention time.

\section{Effect of heat}

Under dry thermal stress condition, ceritinib was degraded about $12.23 \%$ with degradation product at retention time of about 2.58 and $6.83 \mathrm{~min}$.

\section{Effect of light}

When ceritinib in solution state was exposed to sun light; and ceritinib in powder state was exposed to UV light, no degradation was observed, respectively. 
Table V. System suitability test parameters $(n=6)$

\begin{tabular}{cccc}
\hline No. & Retention time, Min. & Tailing factor & Theoretical plates \\
\hline $\mathbf{1}$ & 4.41 & 1.49 & 9282.12 \\
$\mathbf{2}$ & 4.41 & 1.49 & 9254.23 \\
$\mathbf{3}$ & 4.35 & 1.48 & 9237.48 \\
$\mathbf{4}$ & 4.27 & 1.49 & 9187.75 \\
$\mathbf{5}$ & 4.38 & 1.47 & 9265.58 \\
$\mathbf{6}$ & 4.41 & 1.45 & 9176.38 \\
Mean & 4.37 & 1.48 & 9233.92 \\
SD & 0.055 & 0.016 & 42.88 \\
$\mathbf{\%}$ RSD & 1.26 & 1.08 & 0.46 \\
\hline
\end{tabular}

Table VI. Analysis results of tablet dosage form $(n=3)$

\begin{tabular}{cccccccc}
\hline Formulation & Drug & $\begin{array}{c}\text { No. of } \\
\text { Injection }\end{array}$ & $\begin{array}{c}\text { Amount } \\
\text { Taken }\end{array}$ & $\begin{array}{c}\text { Amount } \\
\text { found }\end{array}$ & $\begin{array}{c}\text { Label } \\
\text { Claimed }\end{array}$ & $\begin{array}{c}\text { Amount Found } \\
\text { per Tablet }\end{array}$ & $\begin{array}{c}\text { \% Label } \\
\text { Claim }\end{array}$ \\
\hline ZYKADIA & Ceritinib & 6 & $30 \mathrm{mg}$ & $29.72 \mathrm{mg}$ & $15 \mathrm{mg}$ & $14.86 \mathrm{mg}$ & 99.07 \\
\hline
\end{tabular}

Table VII. Results of stress degradation study

\begin{tabular}{cc}
\hline Stress conditions / duration & \% Degradation \\
\hline Acidic $/ 0.1 \mathrm{~N} \mathrm{HCl}$ & 64.67 \\
Alkaline $/ 0.1 \mathrm{~N} \mathrm{NaOH}$ & 3.70 \\
Oxidative $/ 3 \% \mathrm{H}_{2} \mathrm{O}_{2}$ & 9.50 \\
Thermal $60^{\circ} \mathrm{C}$ & 12.23 \\
\hline
\end{tabular}

The samples exposed to acidic, alkaline, neutral, oxidative, thermal and photolytic conditions were colorless. In Photolytic stability, ceritinib was found to be stable showing no degradation. All degradates were resolved from ceritinib peak and the percentage degradation for each condition indicated that there was no interference from degradates in determination of the ceritinib in tablet dosage form. Thus, the proposed, method was found to be "Stability Indicating".

\section{CONCLUSION}

An isocratic stability indicating reverse phase liquid chromatographic method has been developed and validated for the estimation of ceritinib in tablet dosage form, the method was found to be specific as there was no interference of any co-eluting impurities after stress degradation study. The proposed method was found to be simple, accurate, precise, sensitive and robust. Hence, it can be used successfully for the routine analysis of ceritinib in pharmaceutical dosage forms, and for analysis of stability samples obtained during accelerated stability study

\section{ACKNOWLEDGEMENT}

We are grateful to Dr. Rajendra Gode College of Pharmacy, for supporting this research.

\section{REFERENCES}

Chintala R., Sureshbabu K., Nageshwarao M., 2015, Asian J Pharm and Clin Res; vol-8 issue-3; 44-50

Heudi O., Vogel D., Lau YY., Picard F., Kretz O., 2014, Liquid chromatography tandem mass spectrometry method for the quantitative analysis of Ceritinib in human plasma and its application to pharmacokinetic studies. Anal Bioanal Chem; 406(28):7389-96.

International Conference on Harmonization (ICH), Harmonized Tripartite Guideline, Stability testing of New Drug Substances and Products, 2005, ICH, Q1A (R2), Geneva. 
International Conference on Harmonization (ICH), Harmonized Tripartite Guideline, Validation of Analytical Procedures: Text and Methodology, 2005, Q2 (R1), Geneva.

Kumar CN., Prathyusha V., Kannappan N., 2014, A novel validated stability indicating RP-HPLC method development for the estimation of ceritinib in its bulk and finished dosage form as per ICH guidelines. Der Pharm Lett;6(5):339-51.

Lanshoeft C., Heudi O, Raccuglia M., Leuthold LA, Picard F, Kretz O., 2015, Ultrafast quantitative MS-based method for ceritinib analysis in human plasma samples from clinical trial. Bioanalysis; 7(4):425-35.

Reddy K., Pranaya K., Babu K., Tanjeema MA., Ravikumar, Udayshri; 2016, Analytical Method Development and validation for the estimation of Ceritinib by RP-HPLC method in bulk and pharmaceutical dosage form. Int J Chem Pharm Sci; 4(7): 376-380.

Shaw AT., Kim DW., Mehra R., Tan DS., Felip E, Chow LQ, 2014, Ceritinib in ALKrearranged non-small-cell lung cancer. $\mathrm{N}$ Engl J Med; 370(26):1189-97.

Waters NJ., 2014, Evaluation of Drug-Drug Interactions for Oncology Therapies: Invitro - in-vivo Extrapolation Model-based Risk Assessment. Br J Clin Pharmacol. 